\title{
An Assessment of Occurrences of Thunderstorm as an Indicator of Climate Change : A Case Study of Potiskum and its Environs, Yobe State, Nigeria Muhammad Sani Akilu1,2, Muhammad Ibrahim ${ }^{2,3^{*}}$ \\ ${ }^{*}$ Nigerian Meteorological Agency, Potiskum Unit, Yobe State, Nigeria \\ ${ }^{2}$ Department of Environmental Management and Toxicology, Federal University Dutse, Jigawa State, Nigeria \\ ${ }^{3}$ College of Environment, Hohai University, Nanjing, 210098, P. R. China
}

\begin{abstract}
Article Info

Volume 8, Issue 4

Page Number : 526-533

Publication Issue

July-August-2021

\section{Article History}

Accepted : 07 Aug 2021

Published : 14 Aug 2021

This study examines the occurrences of thunderstorm and rainfall as indicator of climate change in Potiskum and its environs through exploring the decadal recorded data of rainfall and thunderstorm. The data obtained were used to analyze the changes and activities of thunderstorms with rainfall, and thunderstorms without rainfall for each month of the 30 years under study. A descriptive and Inferential statistics was employed to determine the frequency and trend of thunderstorm activities as well as the intensity of rainfall. The analysis indicated that there was decrease in thunderstorm occurrences from first decade (1987 - 1996), second (1997 - 2006) to third decade (2007 - 2016). The results also showed that there was an increase of rainfall intensity in the third decade and decrease in second decade. The results further indicated that there was a climatic change in thunderstorm and rainfall activities in Potiskum and its environs during the study period, and this serves as good indicator of climate change in the study area. Therefore, it is recommended that Nigeria should develop capacity for research and data collection, to monitor climate change impacts, formulate and implement policies to protect natural resources, including forests, and conserve energy based on clean and low carbon technologies.
\end{abstract}

Keywords: Thunderstorms, Rainfall, Climate change, Potiskum, Decade

\section{INTRODUCTION}

Thunderstorm is a meteorological phenomenon that can be formed and developed in any geographic location but most frequently within the mid-latitude, where warm, moist air from tropical latitudes collides with cool air from polar latitudes (Rasuly, 1996;
Abdallah et al., 2017). Thunderstorms are responsible for the development and formation of many severe weather phenomena. The frequent thunderstorms and the phenomena that occur along with, pose a great ecological, economic and health hazards. Damage that results from thunderstorms is mainly inflicted by downburst winds, large hailstones 
and flash-flooding caused by heavy precipitation. Strong thunderstorm cells are capable of producing tornadoes and waterspouts (Krinder, 2017; Ibrahim, 2019).

Thunderstorm is considered a very vital climatic factor due to its significant effect as it plays a pivotal role in the formation of rainfall, which dictates the farming calendar in Nigeria. Climate and environmentally related disasters which threaten human security can induce forced migration and produce competition among communities and nations for natural resources such as water and other basic needs, with potential negative consequences for political stability and conflict resolution (Besada \& Sewankambo, 2009; Young \& Ibrahim, 2021). The climate of Nigeria has shown considerable temporal and spatial shifts in its variability and change. Extreme climate and weather events (drought, flood, heat waves, ocean surges, etc.) have become more regular. The impacts of extreme weather and climate may be gradual but they are destructive to lives and property and negatively impact on the economy. Floods have become a perennial challenge with increasing intensity each year, leaving colossal losses and trauma (IPCC, 2007; Angela et al., 2019).

In 2015, nine out of 17 local government Areas of Yobe State were badly affected by floods, which destroyed houses, farmlands and livestock. News Agency of Nigeria (NAN) reported that communities in Nangere, Fune, Potiskum, Bade, Jakusko, Nguru, Tarmuwa, Bursari and Damaturu were affected by the floods (NAN, 2015). Furthermore, in the year 2017, over 160 buildings were destroyed by a rainstorm which wreaked havoc on four villages in the state (Hajara, 2013).

However, the existing literatures on thunderstorm do not differentiate between thunderstorms with rainfall and thunderstorm without rainfall, and there is no study linking thunderstorm with climate change in the study area. Hence, it is becoming imperative to study the thunderstorm with rainfall and without rainfall and link it with climate change.

Therefore, this study focused on investigating the changes in trend and the intensity of thunderstorms for the maximum period of 30 years as an indicator of climate change in the study area. And to achieve this, the following specific objectives had to be addressed:

(i) Determination of the occurrences of thunderstorm in Potiskum and its environs from 1987 to 2016 (ii) Evaluation of the trend of thunderstorm occurrences in Potiskum and the environs from 1987 to 2016.

\section{METHODOLOGY}

\subsection{Study Area}

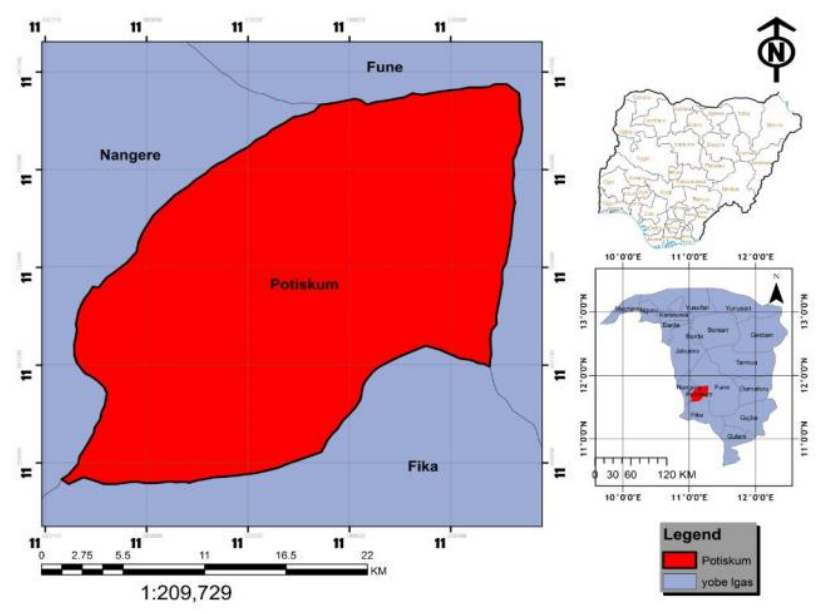

Figure 1: Map of the Study Area. Source: GIS Laboratory Federal University Dutse, Nigeria

\subsection{Location}

Potiskum is the headquarters of Potiskum Local Government Area, Yobe State, North-Eastern Nigeria. It is located in the western part of Yobe on the A3 highway between Longitudes $11^{\circ} 42^{\prime} 33^{\prime \prime} \mathrm{N}$ and $11.70917^{\circ} \mathrm{N}$ and Latitudes $11^{\circ} 04^{\prime} 10^{\prime \prime} \mathrm{E}$ and $11.06944^{\circ} \mathrm{E}$. It has an area of 559 square kilometres and a population of 205,876 according to the 2006 census (Okpachu, et al., 2017; Ibrahim et al., 2017; ).

\subsection{Climate}

The climate of Potiskum is hot and dry for most period of the year. The mean temperature is about 
$37^{\circ} \mathrm{C}$. The highest temperature (about $43^{\circ} \mathrm{C}$ ) is normally experienced in April and May while minimum temperatures (about $12^{\circ} \mathrm{C}$ ) are usually recorded in December and January. The main climatic control of Potiskum and the environs is the interplay between the Tropical continental (cT) air mass and the Tropical maritime (mT) air mass. Their meeting point which is the inter-tropical discontinuity (ITD), is the main factor controlling the weather and climate of the area. The northward advancement of ITD is associated with southerly winds causing rains while the southward retreat is associated with northerly wind reflected in decrease in temperatures and rainfall characteristics_(NIMET, 2010).

The general effects of the climatic controls and the temporal variations in rainfall and temperature conditions give Potiskum and its environs not just dry and wet season as commonly believed but four different seasons which are: (i) The dry and cool season (kaka) that starts around early November and ends in February and it is characterized by cool and dry weather conditions with occasional dusty harmattan haze, as well as low temperatures, evaporation, and relative humidity but has high solar radiation. (ii) The dry and hot season (bazara), which is a short transitional period between the harmattan and wet season. It starts at the end of the cool season and around mid-May with variable winds flow and very high temperatures of over $42^{\circ} \mathrm{C}$, low relative humidity but high evaporation and solar radiation. (iii) The wet and warm season (damina) that starts at the end of hot season and ends around late September to mid-October. This is the proper wet season in the area when over $90 \%$ of the annual rainfall is recorded and southerly winds prevail. The temperature is warm and steady; resulting in the lowest diurnal and monthly ranges of temperature. The season is characterized by high rainfall and relatively high evapotranspiration, less sunshine and high relative humidity. (iv) The dry and warm season starts at the ends of the rains and ends around maid-November. It is the second period of the year where the relative humidity is still sufficiently high to make sensible temperature.

\subsection{Sources of Data}

The rainfall and thunderstorm data used in this study, were sourced from Nigerian Meteorological Agency Potiskum Office in Yobe State.

\subsection{Statistical Analyses}

Descriptive and Inferential statistics was employed using SPSS and Microsoft Excel software. The descriptive statistics was used to analyze the data for thunderstorms with rainfall and thunderstorms without rainfall for each month of the 30 years under study. It was also used to determine the trend of thunderstorms both with rainfall and without rain on monthly and decadal basis for the study period.

\section{RESULTS AND DISCUSSION}

\subsection{Thunderstorm Occurrences on Decadal Basis}

Figure 2 shows monthly trend of thunderstorms at first, second and third decade. The result shows that the second decade has the highest thunderstorms with frequency of 175 , followed by first decade with frequency of 112, while the third decade has the least record with frequency of 96.

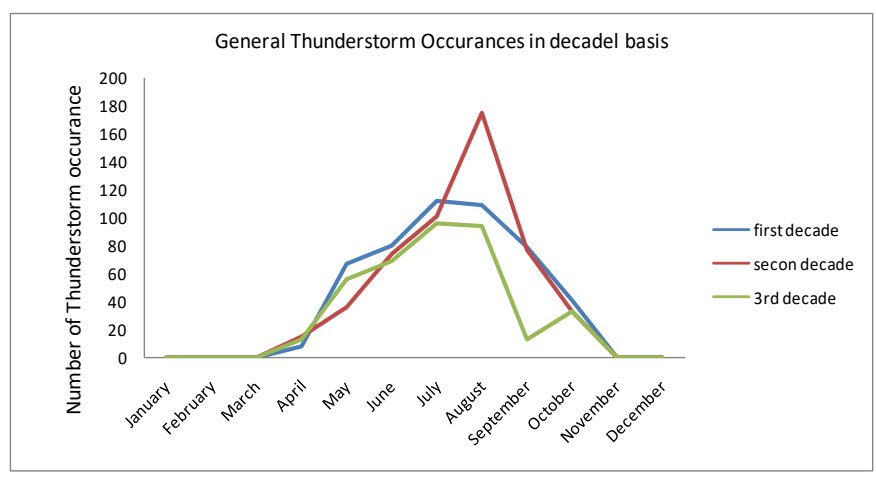

Figure 2 : Thunderstorm occurrences on decadal basis

The student test revealed that thunderstorm occurrence varies significantly in the study area between the first and third decade and between 
second and third decade. However, the variation between first and second decade was found to be insignificant as shown in Table 1.

A similar research was conducted in 1998 by Adelekan, who examined the spatial and temporal variations in thunderstorm rainfall over Nigeria using daily rainfall data and associated weather information over the period of 30 years (1960 - 1989) for 19 synoptic stations. His findings showed the general decrease of thunderstorm activity from south to north.

Table 1: Result of Student $\mathrm{t}$ Test

\begin{tabular}{cccccc}
\hline $\begin{array}{c}\text { 1st Decade } \\
\text { (Mean) }\end{array}$ & $\begin{array}{c}\text { 2nd Decade } \\
(\text { Mean) }\end{array}$ & Variance & T- Value & Significance & Remarks \\
\hline 41.33 & 42.58 & 2072.61 & -0.061 & 0.952 & $\begin{array}{c}\text { Non- } \\
\text { Significant }\end{array}$ \\
\hline $\begin{array}{c}\text { 1st Decade } \\
\text { (Mean) }\end{array}$ & $\begin{array}{c}\text { 3rd Decade } \\
\text { (Mean) }\end{array}$ & Variance & T- Value & Significance & Remarks \\
\hline 41.33 & 31.17 & 1429.06 & 0.595 & 0.558 & Significant \\
\hline $\begin{array}{c}\text { 2nd Decade } \\
\text { (Mean) }\end{array}$ & $\begin{array}{c}\text { 3rd Decade } \\
\text { (Mean) }\end{array}$ & Variance & T- Value & Significance & Remarks \\
\hline 41.33 & 31.17 & 1429.06 & 0.595 & 0.558 & Significant
\end{tabular}

Furthermore, Nigerian Meteorological Agency (NIMET) highlighted the time series of frequency of thunderstorm occurrence at Abuja in its bulletin. The trend shows an increasing trend in thunderstorm occurrence over Abuja environments and concluded that there was an increase in thunderstorm occurrence due to climate change (Nigeria Climate Review Bulletin, 2011).

Also, a study carried out by Alexander, (2015) examined the Statistical analysis of seasonal temperature variation and thunderstorm activity over Yola, North-Eastern Nigeria. The outcomes of the analyses on the annual thunderstorm occurrence showed a decrease in thunderstorm activity over time throughout the study period. It was observed that more TS tend to occur during wet season than during dry season. Thunderstorm activity within the study area exhibits a mono peak or a single maximum in August.

\subsection{Thunderstorms with Rainfall Occurrences on Decadal Basis}

Figure 3 shows the trend of thunderstorm with rain during the first decade. It started in April with frequency of 5 and recorded the highest frequency of 73 in the month of August and the cessation is in the month of October. It also started in April in the second decade with frequency of 11 and it recorded the highest frequency of 66 in the month of August and the cessation in the month of September with record of 47 frequency. In the third decade, it started in the same month of April with frequency of 5 and it recorded the highest frequency of 61 in the month of August and it shows the cessation in the month of October with frequency of 18 .

In a study of rainfall fluctuations in West Africa for the period of 1901 to 1990, the average of annual rainfalls for the period was used as a baseline against which annual rainfalls were plotted and compared. It was observed that annual rainfall levels from 1971 to 1990 were significantly low compared to the longterm average (Omigbodun, 2013; Numafo-Brempong et al., 2019; Mairiga \& Ibrahim, 2021).

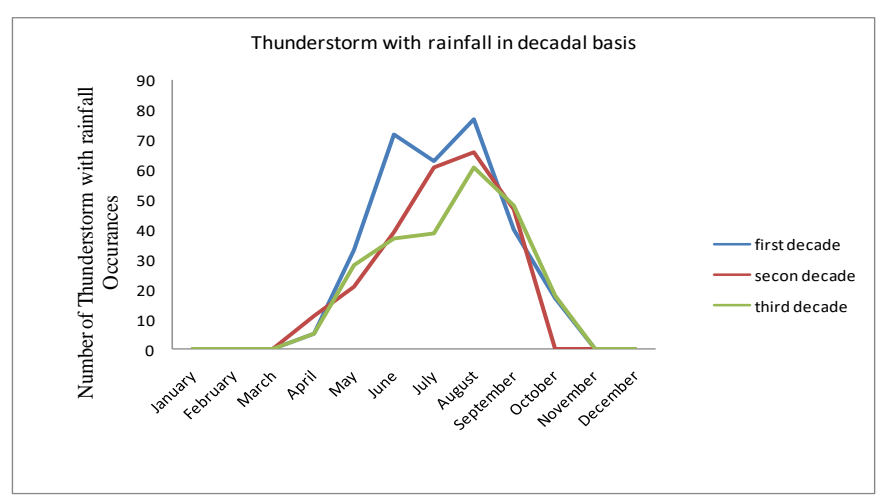

Figure 3 : Thunderstorms with Rainfall on Decadal basis

\subsection{Thunderstorms without Rainfall on Decadal Basis}

Figure 4 shows the trend of thunderstorms without rain. It started in month of April with frequency of 3, and the highest frequency of 39 in the month of 
September. The trend also shows the cessation in the month of October with record of frequency of 24 . It also started in the second decade at the same month with frequency of 4 while recorded the highest frequency of 109 in the same month. The trend shows the cessation in the month of October with frequency of 13. It also shows that the thunderstorms without rain started in the same month during the third decade with frequency of 8 , and recorded the highest frequency of 57 in the month of July. The figure also shows the cessation in the month of October with record of frequency of 15 .

The result of thunderstorm with rain occurrences shows a decrease in thunderstorm activities from first to second and to third decade, and it shows the early onset and early cessation of thunderstorm in first decade. This is in agreement with Alexander, (2015) only in the first and third decade. The result on annual TS occurrence shows a decrease in thunderstorm activity over time during the study period while result of thunderstorm without rain occurrences shows a decrease in thunderstorm activities from first to third decade.

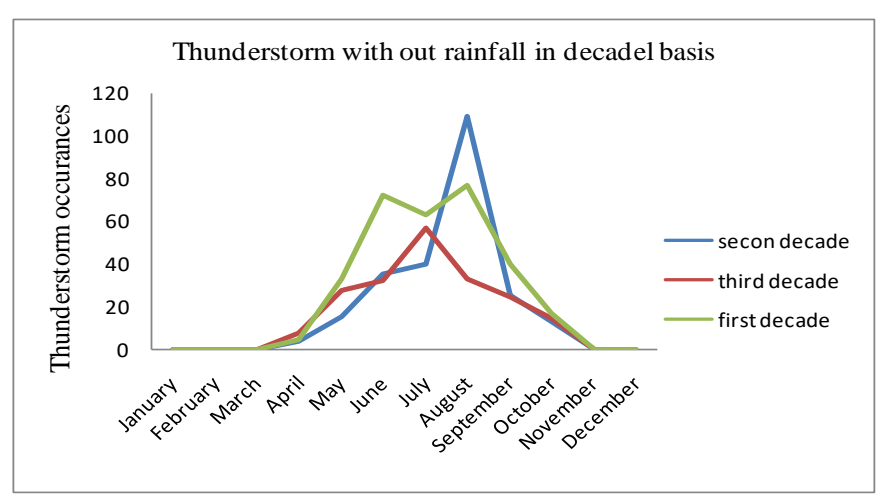

Figure 4 : Thunderstorms without rain in decadal basis

\subsection{Monthly Rainfall on Decadal Basis}

Figure 5 shows that the intensity of rainfall during the first, second and third decade. The third decade has the highest record of rainfall with a peak of $269 \mathrm{~mm}$ in August, followed by first decade with
$239 \mathrm{~mm}$ in the same month. The second decade has the lowest record with $220 \mathrm{~mm}$ in August. This result is in agreement with findings of Sylvester, (2015) who assessed the evidence of Climate change in Bauchi, Nigeria with emphasis to find out if there are changes on the temperature and rainfall over time. The result shows an increase in both temperature and rainfall over time in the study area.

Another study on rainfall in Northern Nigeria covered the area north of latitude $10^{\circ} \mathrm{N}$ with data from Kontagora, Kaduna, Bauchi, Gombe, Yelwa, Samaru, Potiskum, Birnin Kebbi, Gusau, Kano, Maiduguri, Sokoto, Katsina, Hadejia and Nguru. Rainfall data for the period 1976 to 2005 was analyzed and the results showed that the rains now start late but end early and thus the length of the rainy season is decreasing. The frequency of dry spells of 5 days is decreasing, while dry spells of 10,15 or more days are on the increase. Northern Nigeria is therefore becoming drier. The study concluded that in Southern Nigeria, there is evidence that the climate oscillates frequently between wet years and dry years (Omigbodun, 2013; Khadija \& Ibrahim, 2019).

NIMET carried out a review of the climate over Nigeria in 2010. The review indicated that warmer than normal conditions prevailed over greater parts of the country. It was also found that rainfall amounts in 2010 over the country were generally higher than long-term mean values (NIMET, 2010; Ibrahim et al., 2021).

Rainfall data provided by NIMET for Iseyin and Shaki in Oyo North for the period 1990 to 2010 showed a pattern of wet years followed by dry years. Maximum rainfall was at 4 - year intervals, with a minimum two years after a maximum. There was noticeable drought in the northern parts of West Africa between 1968 and 1973. The rainfall that has been observed in 2010, 2011 and 2012 in Nigeria would suggest that we might be in a period of higher-than-average rainfall. 


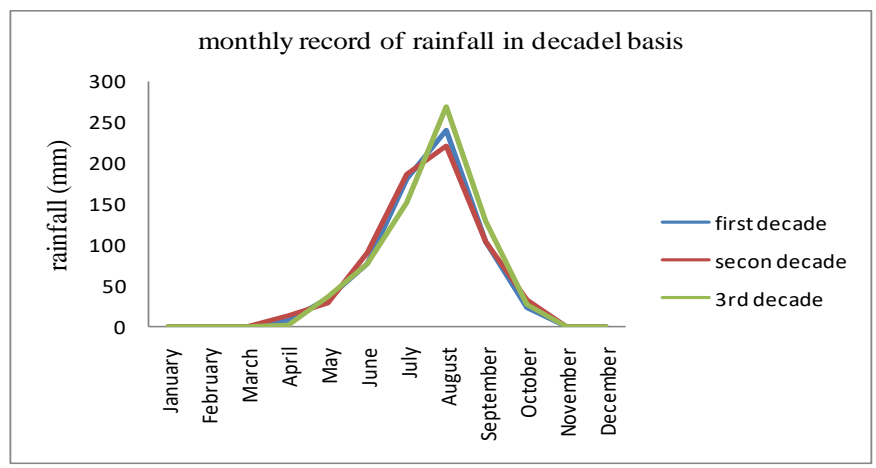

Figure 5: Monthly Rainfall on Decadal Basis

\subsection{Thunderstorm occurrences and Rainfall on Yearly Basis}

The analysis of the trend of thunderstorm occurrence and intensity of rainfall in yearly basis indicated the highest rainfall record of $966.1 \mathrm{~mm}$ in the year 1988 and the lowest record of $410 \mathrm{~mm}$ in 1990 . However, in terms of thunderstorm, it has the highest record in 1994 with frequency of 61.

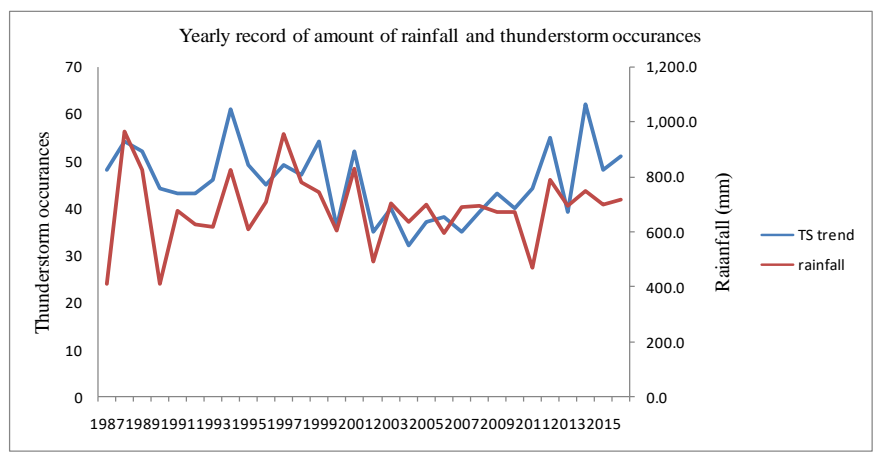

Figure 6 : Rainfall and Thunderstorm occurrences on Yearly Basis

Others who had carried out research on thunderstorm activity in Nigeria include, Mulero (1973) on seasonal distribution of thunderstorm days in Nigeria for the period (1962-1971). Balogun (1981) investigated seasonal and spatial variation of thunderstorm activity in Nigeria and Oladipo and Mornu (1985) discussed the characteristics of thunderstorm in Zaria, Nigeria.
Karen et al., (2014) investigated the impact of climate change on thunderstorms, one of the weather occurrences most problematic for human life on the planet. The varying frequency and intensity of thunderstorms have direct repercussions for the public, agriculture, and industry. The study also observed that satellites have only provided snapshots of thunderstorm incidences. A new map of thunderstorms around the world produced by the study is the first of its kind. The study also observed that there is the need to use algorithm to determine how climate change will affect the frequency and intensity of thunderstorms. According to climate change predictions, every one percent rise in global temperature will lead to a 10 percent increase in thunderstorm activity. This means there may be 25 percent more lightning increase between now and the end of the century (Karen et al., 2014; Ibrahim et al., 2017).

\section{CONCLUSION}

This study found that there is an oscillating pattern of thunderstorm with rainfall and thunderstorm without rainfall in Potiskum and its environs. The findings also showed that there is decrease in thunderstorm activities in the third decade, likewise the frequency of thunderstorm with rainfall decreases from first decade, second, and to third decade. It is therefore concluded that the thunderstorm frequency of occurrence was low during the first, second and third decade, while the intensity was highest in third decade followed by first and second decade. This indicates that there is climatic change in thunderstorm activities in Potiskum and its environs.

\section{ACKNOWLEDGMENT}

The authors wish to acknowledge the support given by the staff of Nigerian Meteorological Agency for the provision of data. Also, our sincere thanks go to the Research Team of Prof. Chen Deqiang and other 
fellow research assistants in the College of Environment, Hohai University Nanjing, P. R. China for their immense contributions towards compiling this article.

\section{REFERENCES}

[1]. Abdallah, M. S., Ibrahim, M., \& Warodi, F. A. (2017). REVIEW ON SOME PLANTS AS BIO PESTICIDES. International Journal of Contemporary Research and Review. https://doi.org/10.15520/ijcrr/2017/8/07/203

[2]. Adelekan, 1. O. (1998). Spatio-temporal variation in thunderstorm rainfall over Nigeria. Climatology (18): 1273-1283.

[3]. Alexander, C. B. (2015). Statistical analysis of seasonal temperature variation and thunderstorm activity over Yola, North-East Nigeria. Educational Research 3(7):873-880

[4]. Angela, A. D., Jennifer, M., \& Ibrahim, M. (2019). Assessment of the Quality of Water from Rooftops (A Case Study of "Nkamponasi" in Tarkwa, Ghana). International Journal of Scientific and Research Publications (IJSRP), 9(5), p8941. https://doi.org/10.29322/ijsrp.9.05.2019.p8941

[5]. Balogun, E. E., (1981). Seasonal and spatial variation of thunderstorm activity over Nigeria.Weather, (36): 192-197

[6]. Besada, H. \& Sewankambo, N. (eds) (2009). Adaptation, Mitigation and Governance Challenges. Special Report: Climate Change in Africa. CIGI

[7]. Hajara Lawan (2013). Hundred rendered homeless in Yobe due to flooding. April 11 2013 information Nigeria, 2017

[8]. Ibrahim, M, Daniel, A. K., Kiyawa, S. A., \& Kutama, A. S. (2017). Phyto-Accumulation of Lead and Chromium in Common Edible GreenLeafy Vegetables Consumed in Dutse Metropolis, Jigawa State, Nigeria. In International Jour. In International Journal of
Chemical, Material and Environmental Research (Vol. 2017, Issue 3). www.ijcmer.org

[9]. Ibrahim, Muhammad. (2019). Air Quality Analyses for Photochemical Smog Associated with Atmospheric Aerosol Particles and Ozone Precursors Using CMAQ and CAMx Modeling Systems. International Journal of Scientific Research in Science and Technology, 224-235. https://doi.org/10.32628/ijsrst196530

[10]. Ibrahim, Muhammad, Young, A. C., Chen, D., \& Mughal, N. (2021). Potential ecological risk, in-situ phytoextraction potential of Lycopersicon esculentum, and pollution indices of selected toxic metals in Hausawan - Kaba, Kano State, Nigeria. Environmental Challenges, 4(March), 100113. https://doi.org/10.1016/j.envc.2021.100113

[11]. IPCC (2007). Fourth Assessment Report, Cambridge, University of Cambridge Press.

[12]. Karen, M., Colin, P. and Eli, G. (2014). The spatial and temporal distribution of global thunderstorm cells. Columbia University, New York, NY, USA

[13]. Khadija, B. U., \& Ibrahim, M. (2019). Assessment of the Pollution extent of Sulphur Dioxide (SO2) and Nitrogen Dioxide (NO2) in Ambient air within Kano Metropolis, Kano State, Nigeria. Journal of Environmental Science, Computer Science And Engineering \& Technology, 8(8), 396-404. https://doi.org/10.24214/jecet.A.8.4.39604.

[14]. Krinder, E.P. (2017). Thunderstorm.: Encyclopædia Britannica. Retrieved from https://www.britannica.com/science/thundersto rm on 14 April, 2017

[15]. Mairiga, N. M., \& Ibrahim, M. (2021). Assessment of Indigenous Knowledge in Managing Environmental Challenges: A Case Study of Ringim Local Government Area of Jigawa State, Nigeria. International Journal of Scientific Advances 2(4), 606-611. https://doi.org/10.51542/ijscia.v2i4.25 
[16]. Mulero, M.A. (1973). Seasonal distribution of thunderstorm days in Nigeria. Meteorology (3): 73-78

[17]. News Agency of Nigeria (2015) National Tragedy: Floods kill 53, displace 100,420 people NIMET (2010). Nigeria climate review bulletin (004): 1-14

[18]. Numafo-Brempong, L., Dawoe, E., \& Ibrahim, M. (2019). Assessment of the Effect of Biochar and Leucaena Leucocephala on the Growth and Yield of Maize (Zea mays). International Journal of Scientific Research in Science and Technology, 34-45. https://doi.org/10.32628/ijsrst19641

[19]. Oladipo, E. O. \& M. E. Mornu, (1985). Characteristics of thunderstorms in Zaria, Nigeria, Weather (4): 316 - 32

[20]. Omigbodun A, (2016). Climate change: Any impact on Nigeria? Vanguard Newspaper, December 17, 2016

[21]. Okpachu, S. A.N, Madu, U. V. \& Okpachu, G. A. (2017) Assessment of rural farm household poverty: Evidence from Potiskum local government area of Yobe State, Nigeria Agricultural Research (2): 022 - 027

[22]. Rasuly, A.A (1996). Temporal and spatial study of Thunderstorm rainfall in the Great Synney Region (Doctor of Philosophy thesis, school of geosciences University of Wollongon, 1996) on line at http://ro.uow.edu.au/thesis

[23]. Sylvester, O, Abdulquadir, I. (2015) Anssessment of evidence of climate change in Bauchi, Nigeria. Applied sciences (3): 375-381

[24]. Young, A. C., \& Ibrahim, M. (2021). Bioaccumulation of Heavy Metals in Lycopersicon Esculentum Grown with Tannery Sludge across Some Selected Farmlands in Dawakin Kudu LGA of Kano State, Nigeria. International Journal of Scientific Research in Science and Technology, 251-257. https://doi.org/10.32628/ijsrst218238

\section{Cite this article as :}

Muhammad Sani Akilu, Muhammad Ibrahim, "An Assessment of Occurrences of Thunderstorm as an Indicator of Climate Change : A Case Study of Potiskum and its Environs, Yobe State, Nigeria", International Journal of Scientific Research in Science and Technology (IJSRST), Online ISSN : 2395-602X, Print ISSN : 2395-6011, Volume 8 Issue 4, pp. 526-533, July-August 2021. Available at doi : https://doi.org/10.32628/IJSRST218480 Journal URL : https://ijsrst.com/IJSRST218480 